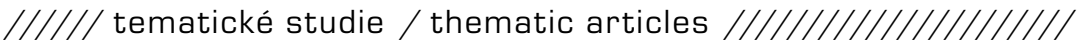

\section{RENAISSANCE ANATOMY: THE PATH FROM ARS TO SCIENTIA WITH A FOCUS ON ANATOMICAL WORKS OF JOHANNES JESSENIUS ${ }^{\star}$}

Abstract: Johannes Jessenius (1566-1621) became known by his contemporaries mostly as an exponent of the Italian anatomical Renaissance in Central Europe at the end of the sixteenth and at the beginning of the seventeenth century. The image of Jessenius in the twentieth century was also created with respect to his activities in the area of anatomy in Wittenberg and Prague in particular. The aim of this article is to put Jessenius into the context of the development of anatomy in the sixteenth century. An important point in this progression can be seen in the change of the definition of anatomy from the art (ars) of dissecting bodies and a "method" of instructing students to the way of acquiring knowledge (scientia) of bodies and nature. The crucial role in this process played anatomical writings of the second half of the 16th century and the development seems to be connected with methodological discussions at the University of Padua. Jessenius, in his anatomical writings, primarily followed the Paduan anatomist Andreas Vesalius (1514-1564), whose work De humani corporis fabrica (1543) expresses the fundamental change in Renaissance anatomy. In addition, the methodological background of the anatomical Renaissance, which Jessenius became acquainted with during his studies in Padua, also echoes in Jessenius' works.

Keywords: renaissance anatomy;

Renaissance methodology; Johannes Jessenius

\section{Renesanční anatomie: od ars ke scientia na př́kladu anatomického díla Jana Jessenia}

\begin{abstract}
Abstrakt: Jan Jesenský - Jessenius (15661621) se pro své současníky stal známým především jako predstavitel italské anatomické renesance ve střední Evropě na prelomu šestnáctého a sedmnáctého století. I ve dvacátém století byl obraz Jana Jesenského vykreslen s ohledem na jeho anatomické aktivity ve Wittenbergu a v Praze. Cílem tohoto článku je zasadit Jessenia do kontextu rozvoje anatomie $v$ šestnáctém století. Významný moment $v$ jejím vývoji lze spatrovat ve zmèně chápání anatomie od uméní (ars) pitvy těl a "metody“ výuky studentů ke zpusobu získávání znalostí (scientia) o tělech a prírodě. Klíčovou roli $v$ tomto procesu sehrála anatomická díla druhé poloviny šestnáctého století. Jejich rozvoj je zřejmě spojen s metodologickými diskusemi na univerzitě $v$ Padově. Jesenský ve svých anatomických dílech navazuje v prvé radě na Andrease Vesalia (1514-1564), jehož De humani corporis fabrica (1543) vyjadruje základní proměnu $v$ renesanční anatomii. $V$ Jesseniově díle se odrážejí i metodologické základy anatomické renesance, se kterými se Jesenský seznámil na svých studiích v Padově.
\end{abstract}

Klíčová slova: renesanční anatomie; renesanční metodologie; Jan Jesenský

\section{TOMÁŠ NEJESCHLEBA}

Dept. of Philosophy / Faculty of Arts Palacký University Olomouc Kř́žkovského 12, 77180 Olomouc email / Tomas.Nejeschleba@upol.cz

(iD) $0000-0003-3130-9302$

The study is a result of the research funded by the Czech Science Foundation as the project GA ČR 19-07439S "Philosophy of Renaissance Medicine in the Czech Lands (Jessenius - Hájek Khunrath - Paracelsus). New Approaches and Contexts."

(c) (1) This work is licenced under the Creative Commons Attribution 4.0 International License.

* This study is dedicated to František Šimon on the occasion of his 70th Birthday. 


\section{Jessenius and Vesalius}

In his anatomical works, Johannes Jessenius ${ }^{1}$ mostly follows famous anatomist Andreas Vesalius. It is apparent in two books edited by Jessenius. Firstly, his description of a public dissection ${ }^{2}$ he performed in Prague is particularly dependent on Vesalius' De humani corporis fabrica. ${ }^{3}$ This finding is quite surprising, since at the beginning of the seventeenth century Vesalius' work could be replaced by the writings of younger anatomists who had already corrected his errors and referred to new findings. The connection of Jessenius' Prague Anatomy with Vesalius' Fabrica is so close that it was even considered an excerpt from Vesalius with certain minor changes. In particular, Jessenius borrows the description of the eye and the speech of his teacher from Padua, Girolamo Fabrici ab Aquapendente, ${ }^{4}$ and although he mentions certain other Renaissance anatomists here and there, such as Realdo Colombo, Vesalius' Fabrica is his main source.

Secondly, Jessenius proclaimed his dependence on Vesalius by means of editing Vesalius' Anatomicarum Gabrielis Fallopii observationum examen. ${ }^{5}$ Andreas Vesalius wrote it as a response to the book Observationes anatomicae written by Gabriele Fallopio (1523-1562) which contained a critique of his De humani corporis fabrica. In the form of a friendly letter, Vesalius

\footnotetext{
${ }^{1}$ To Jessenius' biography emphasizing his activities in the area of anatomy cf. David Kachlik et al., "The Life and Work of Jan Jesensky (1566-1621), the Physician of a Dying Time," Journal of Medical Biography 21, no. 3 (2013): 153-63; David Kachlik et al., "A Biographical Sketch of Johannes Jessenius: 410th Anniversary of His Prague Dissection," Clinical Anatomy 25, no. 2 (2012): 149-54.

${ }^{2}$ The first public dissection in Prague was performed in 1600 and its description was published one year later in Wittenberg. Johannes Jessenius, Anatomiae, Pragae, Anno MDC abs se solenniter administratae historia (Wittebergae: Laurentius Seuberlich, 1601). Cf. the facsimile of the edition together with the Czech translation: Johannes Jessenius, Průběh pitvy jim slavnostně provedenév Praze L. P. MDC, $k$ níž byl přičleněn Traktát o kostech, trans. Bohdana Divišová et al. (Praha: Karolinum, 2004).

${ }^{3}$ Ladislav Borovanský, "Vzpomínka na Jessenia," in Jan Jessenius z Jasené, Průběh pitvy, 11-27; Josef Stingl and Vladimír Musil, "Struktura a obsah Jesseniovy knihy 'Iohannis Jessenii a Iessen, Anatomiae, Pragae, Anno M. D. C abs se solenniter administratae historia," in Ján Jessenius: Slováci na panovníckych dvoroch. Zborník prác z interdisciplinárnej konferencie, ktorá sa konala 13.-14. septembra 2011 v Martine, eds. Agáta Klimeková and Eva Augustínová (Martin: Slovenská národná knižnica, 2012), 11-21.

${ }^{4}$ Borovanský, "Vzpomínka Na Jessenia," 19. Jessenius could gain knowledge from Hieronymus Fabricius ab Aquapendente, De visione, voce, auditu (Venetiis: Francesco Bolzetta, 1600).

${ }^{5}$ Andreas Vesalius, Anatomicarum Gabrielis Fallopii observationum examen. Magni, humani corporis fabricae operis appendix, ed. Johannes Jessenius (Hannoviae: Typis Wechelianis apud Claudium Marnium et haeredes Ioan. Aubrii, 1609).
} 
vindicates himself with respect to some findings which he allegedly made but did not include in his Fabrica. The book was published only in 1564, two years after the death of Fallopio, and was later reedited as an appendix to Fabrica.

Jessenius' aim seems to be to edit the Examen at the time when Fallopio's works were published ${ }^{6}$ and thereby to highlight Vesalius against his critic. In the foreword to the edition, which is a dedication to Heinrich Julius, the duke of Braunschweig, Jessenius presents a short biography of Vesalius.? Here, Jessenius celebrates the pioneering work of Vesalius in the field of anatomy calling him a man who restored a long forgotten anatomical theater. ${ }^{8}$ In Jessenius, Vesalius plays a crucial role in the anatomical Renaissance and as a founder of a new approach in anatomy surpasses his forerunners, contemporaries and immediate followers.

Jessenius' characterization of Vesalius corresponds to Vesalius' own understanding of his contribution to anatomy and medicine in general. Vesalius in the foreword to his book De humani corporis fabrica complains, that "when all operations were entrusted to barbers, not only did true knowledge of the viscera perish from the medical profession, but the work of dissection completely died out. Physicians did not undertake surgery, while those to whom the manual craft was entrusted were too uneducated to understand what professors of dissection had written."

It seems from this quotation that Vesalius' aim was to provide an improved understanding of the ancient anatomical texts. Indeed, in the middle ages and even in the early renaissance, the teaching of anatomy was based on reading authoritative texts. It can be demonstrated by means of illustrations accompanying anatomical books of the late fifteenth century. The anatomist depicted there is a teacher siting in the chair above the human cadaver and

\footnotetext{
${ }^{6}$ Both the edition of Vesalius' Fabrica of 1543 and of 1555 were printed in a relatively high print run, see Dániel Margócsy, Mark Somos, and Stephen N. Joffe, The Fabrica of Andreas Vesalius. A Worldwide Descriptive Census, Ownership, and Annotations of the 1543 and 1555 Editions (Leiden: Brill, 2018), 9. Falloppio's Opera omnia were published in Venice in 1584 and 1606 and in Frankfurt a. M in 1584/5 and 1600. According to Pick they were better accessible then Vesalius' Fabrica, see Friedel Pick, Johannes Jessenius de Magna Jessen. Arzt und Rektor in Wittenberg und Prag hingerichtet am 21. Juni 1621. Ein Lebensbild aus der Zeit des dreissigjährigen Krieges (Leipzig: Barth, 1926), 171.

${ }^{7}$ Vesalius, Anatomicarum Gabrielis Fallopii observationum examen, 3-9.

8 "Cui viro collapsi et diu iacentis theatri anatomici debetur restauratio." Ibid., 6.

${ }^{9}$ Andreas Vesalius, The Fabric of the Human Body: An Annotated Translation of the 1543 and 1555 Editions of "De Humani Corporis Fabrica Libri Septem," trans. Daniel Garrison and Malcolm Hast (Basel: S. Karger, 2003), 2v-3r.
} 
reading the text as a lecturer, while the dissector, a surgeon or barber surgeon, carries out his work..$^{10}$ In the early sixteenth century, the anatomist as a lector was more important than a process of dissection and a technique of dissecting carrying out by a surgeon. ${ }^{11}$

Nevertheless, the active approach to dissection from the part of an anatomist, propagated in the sixteenth century by Vesalius and his contemporaries, i.e., his own experience in anatomy, leads him not to better understanding of written texts, but to criticism of ancient authorities. While in the early sixteenth century, public anatomies served to demonstrate general anatomical knowledge based on written texts, mostly on Galenic account of anatomy, for Vesalius an experience with dissected bodies by his own hands changed the approach to Classical anatomical authorities.

This can be demonstrated from the frontispiece of Vesalius' Fabrica. ${ }^{12}$ It has a complicated structure and the number of figures depicted there has a symbolic meaning which can be interpreted within the framework of Vesalius' approach to anatomy. Although the exegesis of the frontispiece is vast and most of its highlights are well-known, something that deserves mention is the fact that there are two features of the frontispiece that are characteristic of following anatomical practice and that determined Jessenius' approach as well. Firstly, a man dissecting a cadaver is the anatomist, Vesalius himself, while barbers and surgeons who are losing their jobs, sit below the table

${ }^{10}$ Cf. Mondino de Luzzi, Anatomia corporis humani (Leipzig: Martin Landsberg, 1493). Although the book was published many years after Mondino's death, cf. Alexandra Mavrodi and George Paraskevas, "Mondino de Luzzi: A Luminous Figure in the Darkness of the Middle Ages," Croatian Medical Journal 55, no. 1 (2014): 50-53, and it cannot be deduced from the title page that all dissections were assigned to barbers, cf. Nancy G. Siraisi, Medieval \& Early Renaissance Medicine: An Introduction to Knowledge and Practice (Chicago: University of Chicago Press, 1990), 87, the illustration still indicates prevailing contemporary anatomical practice. A similar depiction can be found in Johannes de Kethman's Fasciculus medicinae from 1491, cf. Johannes de Ketham, The Fasciculus Medicinae of Johannes de Ketham, Alemanus: Facsimile of the First (Venetian) Edition of 1491, eds. Carl Sudhoff and Charles Singer, trans. Luke Demaitre and Charles Singer (Birmingham, AL: Classics of Medicine Library, 1988); Salvatore DiMaio, Federico Discepola, and Rolando F. Del Maestro, "Il Fasciculo Di Medicina of 1493: Medical Culture through the Eyes of the Artist," Neurosurgery 58, no. 1 (2006): 187-96. ${ }^{11}$ Cf. Cynthia Klestinec, Theaters of Anatomy. Students, Teachers, and Traditions of Dissection in Renaissance Venice (Baltimore: Johns Hopkins University Press, 2011), $19 \mathrm{ff}$.

${ }_{12}$ Andreas Vesalius, Andreae Vesalii Bruxellensis, scholae medicorum patavinae professoris, de Humani corporis fabrica Libri septem (Basileae: ex officina Ioannis Oporini, 1543), https:// www.e-rara.ch/bau_1/content/titleinfo/6299027, accessed June 20, 2019. Cf. J. B. de Saunders and Charles D. O'Malley, eds., The Illustrations from the Works of Andreas Vesalius of Brussels (New York: Dover Publications, 1973). 
needlessly holding their razors and fighting amongst each other. Vesalius himself instructs the audience about the structure of human body based on his own experience in anatomy. The scene depicted in the frontispiece became an iconographical topos of many subsequent anatomical works and expresses the fundamental change in anatomical instruction in the late Renaissance. Secondly, three ancient looking individuals can be recognized in the audience. They probably represent ancient medical authorities, Galen, Hippocrates, and Aristotle. All of them are taking part in Vesalius' dissection, not as supporters of his view but as persons who are instructed by the Renaissance anatomist.

Vesalius' criticism of ancient anatomical authorities is apparent especially by the manner in which the figure that probably represents Aristotle is depicted: the man, in an ancient robe, standing on the right side of the picture and not looking at the dissection itself but staring at the dog in the right corner. There are more animals to be found on the frontispiece. They should indicate the importance of comparative anatomy. If one looks, however, at the dog which Aristotle is gazing at, the dog seems to have a human leg. It was actually Aristotle who based his physiology on his knowledge of animal bodies, since an anatomist seeks out the functions of vegetative and sensitive souls which humans share with animals. Vesalius wants to indicate that this approach can lead to erroneous conclusions.

Thus, for Vesalius, anatomical study is not only the way that future medical men are to be instructed in the anatomy described by ancient authorities. If it is based on experience, the results will correct the views of the ancients. Speaking about Galen in the foreword to his Fabrica, Vasalius claims: "To this man they have all so entrusted their faith that no doctor has been found who believes he has ever discovered even the slightest error in all the anatomical volumes of Galen, much less that such a discovery is possible." and continues: "In fact, you will find many things in Galen which he misunderstood," for he "has departed much more than two hundred times from a true description of the harmony, use, and function of human parts."

We must add, however, that in spite of this criticism of Galen, Vesalius remained Galenic with respect to general anatomical knowledge. Vesalius was subsequently criticized by Fallopio for being too dependent on Galen. This is why Jessenius, being an admirer of Vesalius, later does not accept much from Fallopio and other critics of Vesalius and still praises Galen as the main Classical authority and the crucial source of anatomical knowledge. Nevertheless, the emphasis on experience connected with the technique (ars) of dissecting became a potential for criticising authorities and 
stands in the midpoint of the understanding of anatomy in the middle of the sixteenth century. Vesalius even in this approach actually follows Galen, who exhorted an anatomist to "put his trust not on his books but in his own eyes." For Vesalius, thus, the reading of the texts of ancients must be substituted for by careful "studying of the works of Nature" which offers "the knowledge of true Anatomy."13 The most important authority for anatomical knowledge is not a text written by an ancient thinker but the text is a dissected body in which one can read as a book of nature. ${ }^{14}$

\section{Anatomical Knowledge as Ars or Scientia?}

One should turn to the issue of what kind of discipline medicine and anat-omy in particular was considered to be in Classical times and in the Middle Ages. Only afterwards one can understand the changes in $16^{\text {th }}$ century anatomy which Vesalius represented and which Jessenius and other late Renaissance anatomists follow. The issue concerns the question of whether medicine belongs to the sciences (scientiae) or the arts (artes), which became the topic of Renaissance debates.

The distinction finds its foundation in Aristotle and although the description of differences between ars and scientia is complex and we can find different tendencies in his works how to define crucial concepts, the lower position of artes if compared with practical and theoretical sciences prevailed as a general position accepted in the Middle Ages and early Renaissance.

In this context the ambivalent character of medicine with respect to its goals, which in a certain sense continues to this day, ${ }^{15}$ is apparent. The

${ }^{13}$ Vesalius, The Fabric of the Human Body, preface. It is known that Vesalius remained dependent on Galen in many aspects, for which he was criticized even by his contemporaries, such as the already mentioned Fallopio, see also below, therefore his approach to anatomy must actually be described as "Galenic," see Andrew Cunningham, The Anatomical Renaissance. The Resurrection of the Anatomical Projects of the Ancients (Aldershot: Routledge, 1997), 88-142. Chapter "Vesalius: The Revival of Galenic Anatomy."

${ }^{14}$ Sven Lembke, "Wie der menschliche Leichnahm zu einem Buch der Natur ohne Druckfehler wird. Über den epistemologischen Wert anatomischer Sektionen im Zeitalter Vesals," in Zergliederungen - Anatomie und Wahrnehmung in der frühen Neuzeit, ed. Albert Schirrmeister (Frankfurt am Main: Klostermann, 2005), 19-45. Cf. Jana Madlen Schütte, Medizin im Konflikt. Fakultäten, Märkte und Experten in Deutschen Universitätsstädten des 14. bis 16. Jahrhunderts (Leiden: Brill, 2017), 86ff.

${ }^{15}$ Judy Sadler, "Ideologies of 'Art' and 'Science' in Medicine: The Transition from Medical Care to the Application of Technique in British Medical Profession," in The Dymanics of Sciences and Technology: Social Values, Technical Norms and Scientific Criteria in the Development of 
primary goal of medicine is treatment of individual people, which is a practice based on experience and concerns individuals and knowledge (scientia) about this practice is impossible. ${ }^{16}$ On the other hand, a theoretical knowledge was also considered to be important for the treatment, since it must be based on knowledge of the human body. ${ }^{17}$

The issue also concerns anatomy that is of course not an invention of the Renaissance period. In Classical times it was also considered an art, a practical skill, as to how to dissect human or animal bodies, so it has something to do with individuals and particular things. One cannot even argue that the art of dissection was unknown to medieval medical men. However, if we compare medieval dissections with the rise of anatomy in the sixteenth century, there is a notable difference. In the middle Ages the main authority in anatomy was textual evidence, i.e., Classical and Arabic textual sources. Although it might have been apparent at times that an individual anatomical experience was not in concord with authoritative texts, this never led to a conclusion that textual sources had to be rewritten. The particular experience, the experience with a particular case, could never jeopardize general anatomical knowledge derived from texts and based on physiological theories: Aristotle's philosophical account of physiological processes on one hand and Galen's more detailed description of the human body and functions of the human soul on the other. Thus, anatomical study by means of dissections only helped gain a better understanding of the text, which offered general knowledge. ${ }^{18}$

The approach changed in the sixteenth century as can be demonstrated by means of the above-mentioned Andreas Vesalius' work De humani corpo-

Knowledge, eds. Wolfgang Krohn, Ewin J. Layton Jr., and Peter Weingart (Dordrecht: D. Reidel Publishing Company, 1978), 177-218.

${ }^{16}$ A typical claim expressing the practical and operational character of medicine can be found in Celsus (25 BCE-50), who speaks about the art of medicine, which "promises health to the sick", underlines its practical dimension, that the art is "made not by disputation but by practice." A. Cornelius Celsus, De medicina (On Medicine) Volume I: Books 1-4., trans. Walter George Spencer, Loeb Classical Library 292 (Cambridge, MA: Harvard University Press, 1935), proemium, 32-33.

${ }^{17}$ According to Aristotle, knowledge of universals is needed in medicine, but a medical man must also focus on individuals, otherwise the cure will fail. In the middle ages, the importance of knowledge (scientia) in medicine is stressed by Avicenna, who's Canon medicinae became an authoritative text for many centuries. In the opening passage, Avicenna says: "Medicine is the science, by which the dispositions of the human body are known so that whatever is necessary is removed or healed by it, in order that health should be preserved or, if absent, recovered." Siraisi, Medieval \& Early Renaissance Medicine, 78.

${ }^{18}$ Siraisi, Medieval \& Early Renaissance Medicine, 89. 
ris fabrica from 1543. How it is possible, however, that the sensory cognition of a particular case in the study of anatomy, which was earlier neglected as a source of knowledge, gained the features of a scientific approach in the sense of acquiring knowledge about nature? This can be explained by the growing importance of anatomy in medical training and by the fact that obtaining knowledge based on experience with dissections was bound with the methodological debates in sixteenth century Padua. ${ }^{19}$

The importance of methodological issues in the Renaissance was highlighted by John Randall's celebrated article The Development of Scientific Method in the School of Padua from 1940. ${ }^{20}$ Although it might seem to be quite antiquated, a number of Randall's conclusions are still useful. Firstly, although Padua University was not the only place where these debates took place, the theories of Paduan methodologists can still be considered crucial for the issues. Secondly, the discussions were deeply bound with the teaching of medicine in Padua, where studies at the Faculty of Arts were primarily focused on the requirements of the Faculty of Medicine. In this context, the old question as to whether medicine is an art or a science played a crucial role. This can be seen in the development of Renaissance anatomy in particular.

Concerning medicine and anatomy, two aspects of these debates can be emphasized. Firstly, the formulation of the method which followed Aristotle's theory of demonstration of the Posterior Analytics. This methodology, however, differed from his views in The Physics, in the Nicomachean Ethics, etc. Physicians, however, did have at their disposal Galen's texts, where three methods were distinguished: analysis (resolution), synthesis (composition) and definition. The word "method" became a technical term in the fifteenth century and a number of medical theoreticians of science discussed Galen's work and combined it with Aristotle's theory of demonstration. Aristotle's two kinds of a proof were identified with Galen's doctrines: "demonstration propter quid," a proof of causes from effects, with doctrina compositiva, and "demonstration quia," a proof of effects from causes, with doctrina resolutiva. ${ }^{21}$

${ }^{19}$ Heikki Mikkeli, An Aristotelian Response to Renaissance Humanism: Jacopo Zabarella on the Nature of Arts and Sciences (Helsinki: The Finnish Historical Society, 1992).

${ }^{20}$ John Herman Randall, "The Development of Scientific Method in the School of Padua," Journal of the History of Ideas 1, no. 2 (1940): 177-206.

${ }^{21}$ Cf. Randall, "The Development of Scientific Method in the School of Padua," 185-86. To different issues of the conception of method cf. Daniel A. Di Liscia, Eckhard Kessler, and 
Secondly, the humanistic approach to the source texts, emphasizing knowledge of the original language in which the text was written, revealed that Galen was not speaking here about the method of attaining knowledge, but about the order of a presentation of already achieved knowledge. The humanist exegesis by Niccolo Leoniceno (1428-1524) attacked the confusion caused by a blending of Galen's text with Aristotle's theory of demonstration. In his conclusion, Galen in this context was reduced from a theoretician of science to a theoretician of medical education, who created "ways of teaching in order." 22 The popularity of public dissections for educational purposes at sixteenth century universities can be put into this context.

Both late Medieval and early Renaissance discussions about two kinds of Aristotelian proofs and the relationship between them, and the humanist exegesis of both Galen's and Aristotle's texts enhanced debates about the method at the university in Padua. As it is well known, the scientific method is described by Padua methodologists, by Jacopo Zabarella (1533-1589) in particular, as a method of regress. ${ }^{23}$ The major issue was how we can know the cause from the effect. Is this knowledge of an apodictic character or do we come to the knowledge of the causes of natural effects only in a hypothetical or conjectural fashion? What role does the examination of the intellect play in this process? In Zabarella, the examination by the intellect enables us to clearly cognize the cause, which was earlier known as confused. Only then the regress, the movement back from causes to the effect, will be possible.

My aim is not to analyze in detail the issue of the method of regress in the Padua school. What is of importance, from the point of view of the topic of my paper, is that the Padua anatomists were aware of the method of regress as it was formulated by their colleagues from the Faculty of Arts.

Charlotte Methuen, eds., Method and Order in Renaissance Philosophy of Nature: The Aristotle Commentary Tradition (Aldershot: Ashgate, 1997).

${ }^{22}$ Neal W. Gilbert, Renaissance Concepts of Method (New York: Columbia University Press, 1963), 99-102. For Leoniceno and medical humanism cf. Vivian Nutton, "The Rise of Medical Humanism: Ferrara, 1464-1555," Renaissance Studies 11, no. 1 (1997): 2-19.

${ }^{23}$ Mikkeli, An Aristotelian Response to Renaissance Humanism, 159ff. Cf. Jacopo Zabarella, On Methods. Volume 1: Books I-II, ed. John P. McCaskey (Cambridge, MA: Harvard University Press, 2013); Jacopo Zabarella, On Methods. Volume 2: Books III-IV; On Regressus, ed. John P. McCaskey (Cambridge, MA: Harvard University Press, 2013). To the relationship between method and order in the discussion between Zabarella and Francsco Piccolomini cf. Nicholas Jardine, "Keeping Order in the School of Padua: Jacopo Zabarella and Francesco Piccolomini on the Offices of Philosophy," in Method and Order in Renaissance Philosophy of Nature: The Aristotle Commentary Tradition, eds. Daniel A. Di Liscia, Eckhard Kessler, and Charlotte Methuen (Aldershot: Ashgate, 1997), 183-209. 
It seems that an anatomical observation fulfills the criteria put on the first stage of the method, i.e., the movement from the senses, from effects to confused causes. The examination by the intellect and the regress from the causes to the effects is then not the task of anatomy or of medicine in general.

In the second half of the sixteenth century, instead of following authorities, the method of empirical observation in anatomy was intensified. Gabrielle Fallopio, a pupil of Vesalius, laments the fact that his beloved teacher did not proceed further in the true description of the structure of the human body, despite his criticism of Galen. ${ }^{24} \mathrm{His}$ aforementioned Anatomicae observationes are written in the form of detailed descriptions of the structure of the human body based on his observations and innovations. In his commentary on Galen's book on bones he then defines anatomy as an art which creates the foundation for all medicine. It does not reach the certitude of philosophy, however, more precisely of physiological theories derived from natural philosophy. ${ }^{25}$ Fallopio's position reflects not only the traditional subordination of medicine to philosophy but also echoes contemporary methodological debates.

Not all anatomists were ready, however, to accept this attitude. The increasing significance of anatomical studies and their achievements had an impact on the self-confidence of anatomists. Heiki Mikkeli in his book about Zabarella and medical humanism provides an analysis of the conception of anatomy in certain anatomists. I will follow his exposition and focus on a few of them who were important for Jessenius. Berengario da Carpi (1460-1530) in the first half of the sixteenth century, for example, defined anatomy not only as an art but also as a science (scientia), for it attains knowledge useful for both theoretical medicine and natural philosophy. ${ }^{26}$ Later, Girolamo Fabrici ab Aquapendente (1537-1619), the renowned Padua anatomist of the late sixteenth century revitalizing an Aristotelian anatomical project, advocated the "scientific" character of anatomy. Although anatomy in his view deals primarily with particular things, as a part of natural philosophy it uncovers the causes of their functions and demonstrates the validity of

\footnotetext{
${ }^{24}$ Roger French, Dissection and Vivisection in the European Renaissance (Aldershot: Ashgate, 1999), 185.

25 "Omnia cum sensu fuerit percepta, sunt in causa (289v) ut philosophus facilius causas immutationum et differentias inquirat, medicus autem illa tanquam probata et declarata, suscipit ab anathomico. Ergo Anatomicus erit artifex ille, cui attinebit petractatio huius libri." Gabriele Fallopio, "Expositio in librum Galeni de ossibus," in Omnia Opera (Venetiis: Apud Felicem Valgrisium, 1584), 289r.

${ }^{26}$ Mikkeli, An Aristotelian Response to Renaissance Humanism, 151-52.
} 
these causes. ${ }^{27}$ His contemporary Girolamo Capo di Vacca (Capivaccio, died 1589) considered anatomy as both art and science. It is an art because of its practical part with respect to manual operations in dissections. It is also a science due to its rational character. In spite of the fact that anatomy is based on sense perception, its knowledge has a rational character and thus can be called science (scientia). ${ }^{28}$

We can conclude that anatomy, which was traditionally considered an art of manual operations, acquires a scientific character in the works of late Renaissance anatomists in the sense that it provides knowledge. First, it is based on sense-perception, i.e., on cognition of particular things, which corresponds to the first stage of a formulated method of regress. Second, due to its rational inference it provides a way to the knowledge of causes and to a judgment as to whether particular effects can be deduced from these cognized causes. It corresponds to the second and the third stages of the method of regress. Contemporary philosophers, however, often refute claims laid by anatomists. Jacopo Zabarella still maintains that anatomy is an art, since its proper aim is practical - the health of men. If anatomy states its scientific character as a way of attaining knowledge, it is not anatomy but natural philosophy. ${ }^{29}$

\section{Jessenius on Anatomy}

The works and anatomical activities of Johannes Jessenius must be put into the above described context. As a professor of anatomy and surgery in Wittenberg Jessenius became an ardent promoter of anatomy. ${ }^{30}$ In concord with the rise of anatomy in the sixteenth century he considered it the basis of both an instruction of students of medicine and of knowledge of the human body. It is evidenced especially in his anatomical works, in the concrete in his description of Prague Anatomy and his short invitations to public Wittenberg dissections.

\footnotetext{
${ }^{27}$ Ibid., 155-56. Cf. Andrew Cunningham, The Anatomical Renaissance. The Resurrection of the Anatomical Projects of the Ancients (Aldershot: Routledge, 1997).

${ }^{28}$ Mikkeli, An Aristotelian Response to Renaissance Humanism, 156-58.

${ }^{29}$ Ibid., 163.

${ }^{30}$ Vivian Nutton, "Wittenberg Anatomy," in Medicine and the Reformation, eds. Ole Peter Grell and Andrew Cunningham (New York: Routledge, 1993), 11-32; Wolfram Kaiser and Anna Völker, Ars Medica Vitebergensis 1502-1817 (Halle: Martin-Luther-Universität HalleWittenberg, 1980).
} 
As a Padua alumnus, Jessenius was aware of the works of Italian anatomists, not only of the aforementioned thinkers Vesalius and Fallopio. Jessenius characterizes himself as a pupil of Girolamo Fabrici ab Aquapendente. Although it is questionable how much anatomical knowledge Jessenius draws from his lectures, ${ }^{31}$ he certainly has the acquaintance with surgical instruments derived from Aquapendente which Jessenius utilized in his book Institutiones chirurgicae from $1601 .{ }^{32}$ Jessenius also knew works of the anatomist Girolamo Cappo di Vacca. He himself published the book about his semiotics based on lectures of another Padua professor Aemilio Campolongo. ${ }^{33}$ In his own books Jessenius often also quotes other anatomists both ancient and Renaissance, such as the Paduan Vesalius' successor Realdo Colombo. Though all these names were mentioned in Jessenius' works, he still mostly follows Vesalius and Galen in his anatomical writings.

The emphasis on anatomy as a foundation for the training of future medical men can be seen in Jessenius' anatomical activities in his Wittenberg period. Between 1595 and 1602 Jessenius performed in Wittenberg a number of public dissections opened not only for students but also for a general audience. The technique (ars) of dissecting was not entrusted to barbers in Jessenius' public dissections but was mostly his own task together with the explanation of anatomical knowledge. In 1601 he maintains that he had already performed about one hundred dissections of human cadavers and vivisections of animals alone or with someone else, ${ }^{34}$ which means that probably a dissector assisted in certain dissections. ${ }^{35}$ It seems, however, that dissections performed by his own hands prevailed. When compared with the previous anatomical tradition in Wittenberg, Jessenius' activities in this

${ }^{31}$ Fabrici did not teach much at the time when Jessenius was studying in Padua due to his quarrels with German students, cf. Antonio Favaro, Atti della nazione Germanica artista nello studio di Padova (Venezia, 1911), Vol. 1, 286, Jessenius often praised his teacher, cf. Giuseppe Favaro, Contributi alla biografia di Girolamo Fabrici d'Aquapendente (Padova, 1922), 296.

${ }^{32}$ Johannes Jessenius, Institutiones Chirurgicae (Wittebergae: Laurentius Seuberlich, 1601); František Šimon, "Úvod Jesseniových Institutiones Chirurgicae," in Historia Medicinae Slovaca I, Ján Jessenius (1566-1621) - Ludia a doba. Mezinárodná vedecká konferencia konaná 8. decembra 2016, eds. Matěj Gogola and Lukáš Rybár (Bratislava: Oddelenie histórie medicíny a zdravotníctva Ústavu sociálneho lekárstva a lekárskej etiky LF UK, 2017), 37-45.

${ }^{33}$ Johannes Jessenius, SEMEIOTIKE, Seu Nova cognoscendi morbos methodus, Ad analyseos Capivvacinae normam, ab aemylio Campolongo, professore Patavino, expressa (Wittebergae: Laurentius Seuberlich, 1601).

${ }^{34}$ Johannes Jessenius, Academiae Witebergensis Studiosis, S. D. (Witebergae: Seuberlich, 1601).

${ }^{35}$ To the divisions of tasks during dissections between lector, dissector etc. see Andrea Carlino, Books of the Body: Anatomical Ritual and Renaissance Learning (Chicago: Chicago University Press, 1999). 
field are really enormous. ${ }^{36}$ Jessenius printed invitations to his dissections which are a unique source for the history of anatomy in Wittenberg. The earliest invitations are focusing on the justification of anatomy within the medical curriculum at the university. Jessenius rhetorically highlights the anatomy as the most important part of the medicine, which stands at the beginning, in the mid and at the end of the "medical art." ${ }^{37}$ In the description of the Prague Anatomy, Jessenius is clearer in his statement about the importance of anatomy within medicine. Without knowledge of anatomy, which is the crucial part of medicine, it is not useful to know all other branches of medicine. ${ }^{38}$

In his praise of anatomy Jessenius stresses its practical significance as it enables to demonstrate the origins or even causes of the disease. ${ }^{39}$ Thus, anatomy is a necessary condition for treatment since the knowledge of the cause of the disease reveals the way to cure the disease. ${ }^{40}$ In reality, however, only a minority of Jessenius' public dissections were focused on uncovering causes of diseases. ${ }^{41}$ Most of the dissected bodies were those of executed criminals; hence their dissections had an instructive purposes. Jessenius aims to show the audience, in Wittenberg comprised mostly of students, the parts of the human body, beginning with muscles, moving on to viscera and

\footnotetext{
${ }^{36}$ It is said that in the period of one hundred years from the first Wittenberg dissection ten autopsies of the entire number of nineteen were performed by Jessenius. Cf. László Ruttkay, "Jessenius als Professor in Wittenberg. Zum 350. Todesjahr von Jessenius," Orvostorteneti Kozlemenyek. Commutationes de Historia Artis Medicinae 62-63 (1971): 36. Only those of Jesenius' public disections which are textually documented are included in the number.

37 "De quo certe ita ego sentio, ut abs me quaerenti, quidnam in arte medica primum sit, continuo responsurus sim, esse anatomen, et denuo roganti, quid in ipsa medium, anatomen nominarim, quemadmodum etiam, quid in medicina postremum suscitanti, aliud non praeter anatomen ingeminaturus." Jessenius' invitation from August 19, 1600, Jessenius, Academiae Witebergensis Studiosis, S. D.

38 "Adeo ut ignorata hac parte Medicina potissima, inutile sit scire reliquas." Jessenius, Anatomiae, Pragae, A5v.

39 "Universali anatome intimius pervestigabimus, morborum sedes, causas demonstrabimus." Jessenius' invitation from November 1, 1595, Iohan. Iessenius a Iessen, doctor et anatome professor, studiosis humanitatis, The University Library Wroclaw, sig. 522308. Cf. "compendaria anatome in viscera, potissumum naturalia, unde morbi origo, disquirendo." Jessenius' invitation from March 8, 1601, Philosophiae, medicinaeque studiosis, S. D., Doctor Iohan. Iessenius a Iessen anatomicus. Library of the Hungarian Academy of Sciences, sig. RMIr 287.

${ }_{40}$ "Instruit, qua parte morbus veniat, quibus causis vigeat, quam potentilus, unice instituit, hac viam remediis ostendit." Jessenius, Anatomiae, Pragae, A5v.

${ }^{41}$ This is only the case of the public dissection of the cadaver of an eight years old girl, who died by a rare disease, from the March 8,1601 .
} 
ending with bones. Moreover, for dissections were not so oft as Jessenius would wish, his teaching of anatomy was still based on the reading of authoritative texts, mostly of Galen to whom anatomy owes much as Jessenius says. ${ }^{42}$ Public dissections, therefore, had only a supportive role in Jessenius' teaching.

Apart from the pedagogical purpose of anatomy and of its practical function in treatment, Jessenius also attributes anatomy a role in achieving knowledge. At the beginning of his Prague Anatomy, he confesses to his desire to know what man actually is and he consequently claims that anatomy is a discipline which fulfills his aspiration. Anatomy, therefore, does not only have its practical goals in treating people as a part of an art of medicine but also in gaining knowledge (scientia) of the nature of man. The question arises, what is the method, according to Jessenius, of attaining this anatomical knowledge?

The anatomy is based on two sources, firstly on the reading of authoritative texts as was mentioned above and Jessenius highlights Galen in spite of the fact, that this authority was so deeply criticized by Fallopio and other Renaissance anatomists. He probably still considered it useful for instructing future medical man following Vesalius, who's criticism of Galen was not so radical. The second source of anatomical knowledge, however, is its own method. ${ }^{43}$ In concord with the anatomical Renaissance, the proper method of anatomy, according to Jessenius, rises from sensory observation. Our knowledge of the nature of man, or more precisely, of the world in which we can read by means of the senses in the same way as a book, starts with the senses. Moreover, the senses are not only the way through which we cognize the world but the senses also lead to the cognition of God. ${ }^{44}$

42 "Ex quo librorum ordine, adeoque anatomiae methodo, quis rerum aestimator ingenuus non perspiciet et judicabit, quantas huic viro debeamus gratias, sive inventae dicas, sive conservatae medicinae." Jessenius' invitation from August 19, 1600, Academiae Witebergensis studiosis S. D. Iohannes Iessenius a lessen. Library of the Hungarian Academy of Sciences, sig. RMIr III 287. Jessenius presents here the sequence of Galen's books which should be followed in anatomical studies: practical De anatomicis administrationibus should be followed by books on theoretical medicine, De naturalibus facultatibus, De placitis Hippocratis et Platonis, etc.

${ }^{43}$ Cf. note above: "Ex quo librorum ordine, adeoque anatomiae methodo [...]."

44 "Qui totus nil aliud, quam liber omnibus obvius, omnibus apertus, in quo et adulti Deum legere, et infantuli ipsi, ut sic loquar, combinare possunt. [...] Nam sensus, penes quos prima humanae agnitionis schola, Deum testantur." Jessenius' invitation from December 15, 1596, Academiae Witebergensis studiosis, S. P. D., D. Iessenius. Academiae Witebergensis studiosis S. D. Iohannes Iessenius a Iessen. Library of the Hungarian Academy of Sciences, sig. RMIr III 285. 
This theological aspect of anatomy is used by Jessenius as a way of vindicating anatomical practice.$^{45}$ It is derived partially from scholastics Aristotelianism where the Peripatetic emphasis on the senses as the beginning of our knowledge was used for instance in Thomas Aquinas' proofs of God's existence. Sensory cognition of effects leads to rational cognition of their causes and, in the case of Aquinas' proofs, to the cognition of the existence of the first cause. Jessenius transforms this model into the area of medicine as a strategy of defense against attacks made against his activities from the side of Lutheran orthodoxy.

Jessenius emphasizes the sensory character of anatomical observations as the starting point of the knowledge of human nature and consequently of God as well, this emphasis is particularly present in the Prague Anatomy. However, Jessenius subordinates anatomical knowledge to natural philosophy and does not consider it to be knowledge as such, as his contemporaries in Padua Fabrici and Capivaccio tended to.

The dependence of anatomy on natural philosophy is a consequence of a fact that anatomy, since it is based on sensory observation, provides perfect cognition of the parts of animals and comparison of their actions. ${ }^{46}$ Jessenius maintains, that the work of a philosopher is wider, since he deals with all living things. Concerning human nature, a philosopher considers man as a whole compounded from a body and a soul, while an anatomist focuses only on body. It follows that an anatomist, describing and exploring parts of body which are animated by the soul, is dependent on the philosophical conception of the soul. ${ }^{47}$ Only then an anatomist can rightly grasp vegetative and sensitive functions of the soul in organs of the human body he is dissecting.

In his anatomical works, Jessenius does not deal with the issue of the status of anatomy and with the proper anatomical method in the context of methodological debates of his time. He was, however, aware of period controversies on this field. It can be documented by his speech to Wittenberg

\footnotetext{
${ }^{45}$ Tomáš Nejeschleba, "Justification of Anatomical Practice in Jessenius's Prague Anatomy," Early Science and Medicine 21, no. 6 (2016): 557-74.

46 "Cum ergo anatome, quae corporum animalium dissetrix ratione atque judicio opus peragit, perfecta partium cognitionis fine, peritia quaedam sit, haec autem habitus, hic vero iteratis duntaxat actionibus comparandus." Johannes Jessenius, Pro Anatome sua actio. Ad spectandum invitatio (Witebergae: Typis Zachariae Lehmanni, 1600), A2r.

${ }^{47}$ Jessenius deals with various philosophical concepts of the soul in the preface to his Prague Anatomy. Jessenius, Anatomiae, Pragae, 4-6.
} 
students from the same period as his main anatomical work - the description of Prague Anatomy - was written.

Jessenius summarizes in the speech, which was delivered to students of philosophy and medicine, different methods of demonstrations. ${ }^{48}$ The speech is based on Aristotelian doctrine of syllogism with reference to the Posterior analytics which Jessenius relates to epistemological issues. He differentiates four types of cognition according to four fundamental questions of "whether," "that," "what," and "why" a thing is. He considers all these types of cognition to be the ways of knowing (modi sciendi) and creates a series of steps towards the knowledge of something. It begins with the senses which answer the question "whether a thing is." Jessenius calls this way "induction" which is followed by the second step, so-called probable syllogism. It seems that these two ways are characteristic of medicine as an empirical science according to Jessenius. Its conclusions have only probable validity since they come from empirical observations, i.e., from effects, and not from causes. Then philosophy, the third way of knowing, provides a demonstration in the proper sense by deducing effects from their causes. Finally, as the last step towards knowledge, the definition is created. It is obvious that Jessenius follows Paduan methodological discussions and designates for medicine an important role within the structure of knowing. Medicine and anatomy in particular, however, cannot reach perfect knowledge and must be succeeded by philosophy which creates valid demonstrations and definitions. This speech by Jessenius, therefore, clarifies the methodological context, into which his anatomical works must be put.

To sum up, although Jessenius calls anatomy a way how to attain knowledge (scientia anatomica), knowledge provided by anatomical observations is according to him deeply bound and even dependent on natural philosophy. Anatomical observations exploring the structure, functions and usefulness of parts of the human body, are of an empirical character. In this sense Jessenius follows the leading stream of late Renaissance anatomical thought. Anatomical knowledge, however, draws its fundamental concepts and theories about the functions of the parts of the human body from doctrines coming from physiology, a branch of natural philosophy, about the human soul and its relation to the human body. Jessenius is not as radical in his stance on the status of anatomy as his Paduan teachers Girolamo Fabrici ab

${ }^{48}$ Johannes Jessenius, Et philosophiae et medicinae solidae studiosis (Witebergae: Typis M. Iohannis Cratonis, 1600); Tomáš Nejeschleba, "Johannes Jessenius's Conception of Method," Acta Comeniana 20-21, no. 44-45 (2007): 9-23. 
Aquapendente and Girolamo Capo di Vacca were. His emphasis on anatomy based on authoritative texts and the technique of dissecting bodies as the central part of medicine and a starting point of the anatomical knowledge of human nature still corresponds with the results of methodological debates in late sixteenth century Padua during which anatomy was becoming a scientia, meaning a way of attaining knowledge about nature.

\section{Bibliography:}

\section{Primary sources}

Celsus, A. Cornelius. De medicina (On Medicine) Volume I: Books 1-4. Translated by Walter George Spencer. Loeb Classical Library 292. Cambridge, MA: Harvard University Press, 1935. https://doi.org/10.4159/DLCL.celsus-medicine.1935.

Fabricius ab Aquapendente, Hieronymus. De visione, voce, auditu. Venetiis: Francesco Bolzetta, 1600.

Fallopio, Gabriele. "Expositio in librum Galeni de ossibus." In Omnia Opera, 289-330. Venetiis: Apud Felicem Valgrisium, 1584.

Galen. “The Best Doctor is also a Philosopher." In Galen: Selected Works, ed. Peter N. Singer, 30-34. Oxford: Oxford University Press, 1997.

Jessenius, Johannes. Academiae Witebergensis studiosis, S. D. Witebergae:

Seuberlich, 1601.

Jessenius, Johannes. Anatomiae, Pragae, anno MDC abs se solenniter administratae historia. Wittebergae: Laurentius Seuberlich, 1601.

Jessenius, Johannes. Et philosophiae et medicinae solidae studiosis. Witebergae: Typis M. Iohannis Cratonis, 1600.

Jessenius, Johannes. Institutiones chirurgicae. Wittebergae: Laurentius Seuberlich, 1601.

Jessenius, Johannes. Pro anatome sua actio. Ad spectandum invitatio. Witebergae: Typis Zachariae Lehmanni, 1600.

Jessenius, Johannes. Průběh pitvy jím slavnostně provedenév Praze L. P. MDC, $k$ nizz byl přričleněn Traktát o kostech. Trans. Bohdana Divišová, Hana Florianová, Cyril Matouš, Dana Svobodová, and Olga Vodenková. Praha: Karolinum, 2004. 
Jessenius, Johannes. SEMEIOTIKE, Seu nova cognoscendi morbos methodus, Ad analyseos Capivvacinae normam, ab Aemylio Campolongo, professore Patavino, expressa. Wittebergae: Laurentius Seuberlich, 1601.

Ketham, Johannes de. The Fasciculus medicinae of Johannes de Ketham, Alemanus: Facsimile of the First (Venetian) Edition of 1491. Edited by Carl Sudhoff and Charles Singer. Trans. Luke Demaitre and Charles Singer. Birmingham, AL: Classics of Medicine Library, 1988.

Luzzi, Mondino de. Anatomia corporis humani. Leipzig: Martin Landsberg, 1493.

Vesalius, Andreas. Anatomicarum Gabrielis Fallopii observationum examen. Magni, humani corporis fabricae operis appendix. Ed. Johannes Jessenius. Hannoviae: Typis Wechelianis apud Claudium Marnium et haeredes Ioan. Aubrii, 1609.

Vesalius, Andreas. Andreae Vesalii Bruxellensis, scholae medicorum Patavinae professoris, de humani corporis fabrica libri septem. Basileae: ex officina Ioannis Oporini, 1543. https://doi.org/10.5962/bhl.title.109299.

Vesalius, Andreas. The Fabric of the Human Body: An Annotated Translation of the 1543 and 1555 Editions of "De humani corporis fabrica libri septem." Trans. Daniel Garrison and Malcolm Hast. Basel: S. Karger, 2003.

Zabarella, Jacopo. On Methods. Volume 1: Books I-II. Ed. John P. McCaskey. Cambridge, MA: Harvard University Press, 2013.

Zabarella, Jacopo. On Methods. Volume 2: Books III-IV; On Regressus.

Ed. John P. McCaskey. Cambridge, MA: Harvard University Press, 2013.

\section{Secondary sources}

Borovanský, Ladislav. "Vzpomínka na Jessenia." In Jan Jessenius z Jasené. Průběh pitvy jím slavnostně provedené v Praze L.P. MDC, $k$ níž byl přčcleněn Traktát o kostech, 11-27. Praha: Karolinum, 2004.

Carlino, Andrea. Books of the Body: Anatomical Ritual and Renaissance Learning. Chicago: Chicago University Press, 1999.

Cunningham, Andrew. The Anatomical Renaissance. The Resurrection of the Anatomical Projects of the Ancients. Aldershot: Routledge, 1997.

De Saunders, J. B. C., and Charles D. O'Malley, eds. The Illustrations from the Works of Andreas Vesalius of Brussels. New York: Dover Publications, 1973. 
Di Liscia, Daniel A., Eckhard Kessler, and Charlotte Methuen. Method and Order in Renaissance Philosophy of Nature: The Aristotle Commentary Tradition. Aldershot: Ashgate, 1997.

Di Maio, Salvatore, Federico Discepola, and Rolando F. Del Maestro. "Il Fasciculo di medicina of 1493: Medical Culture through the Eyes of the Artist." Neurosurgery 58, no. 1 (2006): 187-96. https://doi.org/10.1227/01.NEU.0000192382.37787.80.

Favaro, Antonio. Atti della nazione germanica artista nello studio di Padova. Venezia, 1911.

Favaro, Giuseppe. Contributi alla biografia di Girolamo Fabrici d'Aquapendente. Padova, 1922.

French, Roger. Dissection and Vivisection in the European Renaissance. Aldershot: Ashgate, 1999.

Gilbert, Neal W. Renaissance Concepts of Method. New York: Columbia University Press, 1963.

Jardine, Nicholas. "Keeping Order in the School of Padua: Jacopo Zabarella and Francesco Piccolomini on the Offices of Philosophy." In Method and Order in Renaissance Philosophy of Nature: The Aristotle Commentary Tradition, eds. Daniel A. Di Liscia, Eckhard Kessler, and Charlotte Methuen, 183-209. Aldershot: Ashgate, 1997.

Kachlik, David, David Vichnar, Dana Kachlikova, Vladimir Musil, Kristian Szabo, and Josef Stingl. "The Life and Work of Jan Jesensky (1566-1621), the Physician of a Dying Time.” Journal of Medical Biography 21, no. 3 (2013): 153-63. https://doi. org/10.1177/0967772013479736.

Kachlik, David, David Vichnar, Vladimir Musil, Dana Kachlikova, Kristian Szabo, and Josef Stingl. "A Biographical Sketch of Johannes Jessenius: 410th Anniversary of His Prague Dissection.” Clinical Anatomy 25, no. 2 (2012): 149-54. https://doi. org/10.1002/ca.21237.

Kaiser, Wolfram, and Anna Völker. Ars Medica Vitebergensis 1502-1817. Halle: Martin-Luther-Universität Halle-Wittenberg, 1980.

Klestinec, Cynthia. Theaters of Anatomy. Students, Teachers, and Traditions of Dissection in Renaissance Venice. Baltimore: Johns Hopkins University Press, 2011.

Lembke, Sven. "Wie der menschliche Leichnahm zu einem Buch der Natur ohne Druckfehler wird. Über den epistemologischen Wert anatomischer Sektionen im 
Zeitalter Vesals.” In Zergliederungen - Anatomie und Wahrnehmung in der frühen Neuzeit, ed. Albert Schirrmeister, 19-45. Frankfurt am Main: Klostermann, 2005.

Margócsy, Dániel, Mark Somos, and Stephen N. Joffe. The Fabrica of Andreas Vesalius. A Worldwide Descriptive Census, Ownership, and Annotations of the 1543 and 1555 Editions. Leiden: Brill, 2018. https://doi.org/10.1163/9789004336308.

Mavrodi, Alexandra, and George Paraskevas. "Mondino de Luzzi: A Luminous Figure in the Darkness of the Middle Ages." Croatian Medical Journal 55, no. 1 (2014): 50-53. https://doi.org/10.3325/cmj.2014.55.50.

Mikkeli, Heikki. An Aristotelian Response to Renaissance Humanism: Jacopo Zabarella on the Nature of Arts and Sciences. Helsinki: The Finnish Historical Society, 1992.

Nejeschleba, Tomáš. “Johannes Jessenius's Conception of Method.” Acta Comeniana 20-21, no. 44-45 (2007): 9-23.

Nejeschleba, Tomáš. "Justification of Anatomical Practice in Jessenius's Prague Anatomy." Early Science and Medicine 21, no. 6 (2016): 557-74. https://doi. org/10.1163/15733823-00216p04.

Nutton, Vivian. “The Rise of Medical Humanism: Ferrara, 1464-1555.” Renaissance Studies 11, no. 1 (1997): 2-19. https://doi.org/10.1111/j.1477-4658.1997.tb00008.x.

Nutton, Vivian. "Wittenberg Anatomy." In Medicine and the Reformation, eds. Ole Peter Grell and Andrew Cunningham, 11-32. New York: Routledge, 1993.

Pick, Friedel. Johannes Jessenius de Magna Jessen. Arzt und Rektor in Wittenberg und Prag hingerichtet am 21. Juni 1621. Ein Lebensbild aus der Zeit des dreissigjährigen Krieges. Leipzig: Barth, 1926.

Randall, John Herman. "The Development of Scientific Method in the School of Padua." Journal of the History of Ideas 1, no. 2 (1940): 177-206. https://doi. org/10.2307/2707332.

Ruttkay, László. “Jessenius als Professor in Wittenberg. Zum 350. Todesjahr von Jessenius." Orvostorteneti kozlemenyek. Commutationes de historia artis medicinae 62-63 (1971): 13-55.

Sadler, Judy. "Ideologies of 'Art' and 'Science' in Medicine: The Transition from Medical Care to the Application of Technique in British Medical Profession." In The Dymanics of Sciences and Technology: Social Values, Technical Norms and Scientific Criteria in the Development of Knowledge, eds. Wolfgang Krohn, 
Ewin J. Layton Jr., and Peter Weingart, 177-218. Dordrecht: D. Reidel Publishing Company, 1978.

Schütte, Jana Madlen. Medizin im Konflikt. Fakultäten, Märkte und Experten in Deutschen Universitätsstädten des 14. bis 16. Jahrhunderts. Leiden: Brill, 2017. https://doi.org/10.1163/9789004331594.

Šimon, František. "Úvod Jesseniových Institutiones chirurgicae." In Historia medicinae slovaca I, Ján Jessenius (1566-1621) - L'udia a doba. Mezinárodná vedecká konferencia konaná 8 . decembra 2016, eds. Matěj Gogola and Lukáš Rybár, 37-45. Bratislava: Oddelenie histórie medicíny a zdravotníctva Ústavu sociálneho lekárstva a lekárskej etiky LF UK, 2017.

Siraisi, Nancy G. Avicenna in Renaissance Italy: The Canon and Medical Teaching in Italian Universities after 1500. Princeton, NJ: Princeton University Press, 1987. https://doi.org/10.1515/9781400858651.

Siraisi, Nancy G. Medieval \& Early Renaissance Medicine: An Introduction to Knowledge and Practice. Chicago: University of Chicago Press, 1990. https://doi. org/10.7208/chicago/9780226761312.001.0001.

Stingl, Josef, and Vladimir Musil. "Struktura a obsah Jesseniovy knihy 'Iohannis Jessenii a Iessen, Anatomiae, Pragae, anno M. D. C abs se solenniter administratae historia."' In Ján Jessenius: Slováci na panovníckych dvoroch. Zborník prác z interdisciplinárnej konferencie, ktorá sa konala 13.-14. septembra 2011 v Martine, eds. Agáta Klimeková and Eva Augustínová, 11-21. Martin: Slovenská národná knižnica, 2012. 